\title{
Diplomasi Pertahanan Militer Indonesia dalam Menghadapi Ancaman Keamanan Non-Tradisional: Upaya Mewujudkan Visi Poros Maritim Dunia
}

\author{
Muhammad Samy dan Jayanti Aarnee Kusumadewi \\ Universitas Airlangga
}

\begin{abstract}
Abstrak
Posisi geografis Indonesia yang terletak di antara dua samudera dan jalur-jalur pelayaran tersibuk di dunia menjadikannya posisi yang strategis. Potensi ini pun dimaksimalkan pada era Presiden Joko Widodo melalui visi Poros Maritim Dunia. Salah satu aspek krusial dalam mewujudkan gagasan ini adalah sektor keamanan. Perairan Indonesia menghadirkan sejumlah rintangan tersendiri, seperti perompakan, terorisme, dan kejahatan transnasional. Untuk menghadapi permasalahan tersebut, salah satu upaya yang digencarkan Indonesia adalah melalui diplomasi pertahanan maritim dalam bentuk kerjasama, baik secara bilateral maupun multilateral. Tulisan ini akan menjelaskan lebih lanjut mengenai bentuk dan implikasi diplomasi pertahanan yang dimaksud, serta mengapa hal tersebut menjadi pilihan kebijakan luar negeri yang diintensifkan dalam menanggapi isu keamanan di perairan Indonesia. Berdasarkan analisis yang telah dilakukan, ditemukan bahwa intensifikasi diplomasi pertahanan maritim dilakukan mengingat terbatasnya kapabilitas sistem pertahanan yang dimiliki Indonesia dalam merespon ancaman maritim dan non-tradisional. Atas konsiderasi tersebut, pengambilan langkah ini menjadi tindakan yang rasional bagi Indonesia untuk mengompensasi kekurangan tersebut.
\end{abstract}

Kata kunci: Indonesia; PMD; Diplomasi Pertahanan Maritim; Keamanan Non-Tradisional; Keamanan Maritim

Sitting between two world's biggest oceans and bussiest shipping lanes, Indonesia's geographic positioning has given it a very strategic leverage. Such potential is then stressed out during the era of President Joko Widodo with his vision of Global Maritime Fulcrum. One of the crucial aspects needed for optimalizationofthisideaissecurity. Indonesianwatershavebeenknowntobequite hostileduetotthreatssuchaspiracy,terrorism, andtransnationalcrimes.Aseriesof maritime defense diplomacy thus have been initiated and intensified-along with other means-to counter them, both bilateral and multilateral in form. This article would elaborate more on the manifestation and implications of those actions made, and why Indonesia specifically focused more on Its maritime defense diplomacy. Based on the findings, it is then revealed that such diplomatic move can be owed to Indonesia's lacking defense system-making diplomacy a rational alternative to compensate for Its flaw in capacity.

Keywords: Indonesia; PMD; Maritime Defense Diplomacy; Non-Traditional Threat; Maritime Security 


\section{Pendahuluan}

Indonesia merupakan negara kepulaun terbesar di dunia dengan luas wilayah laut sebesar 3,25 juta $\mathrm{Km}^{2}$. Selain itu, Indonesia juga memiliki posisi geografis yang strategis karena terletak di antara dua samudra besar, yaitu Pasifik dan Hindia, dan dilewati oleh sejumlah jalur pelayaran tersibuk di dunia, seperti Selat Malaka dan Laut Sulawesi. Lantas, besar potensi bagi Indonesia untuk mendapat keuntungan ekonomis bila terdapat pengembangan yang lebih intensif dalam sektor jasa pelayaran dan perhubungan laut. Optimalisasi kedua sektor tersebut kemudian menjadi salah satu area prioritas kebijakan luar negeri Indonesia pada era kepemimpinan Joko Widodo. Tujuan dari hal tersebut dimanifestasikan dalam narasi untuk menjadikan Indonesia sebagai Poros Maritim Dunia (PMD). Visi ini dicanangkan sebagai respon terhadap dinamika internasional kontemporer, yang mana konsentrasi kekuatan ekonomi dunia mulai bergeser menuju wilayah Asia. Dengan demikian, Indonesia merupakan salah satu negara di kawasan tersebut yang turut berpeluang besar memanfaatkan momentum ini. PMD memiliki setidaknya lima pilar utama yakni ekonomi maritim, infrastruktur maritim, konektivitas maritim, budaya maritim, diplomasi maritim, serta pertahanan maritim (Mundayat et al. 2018). Dua poin terakhir, yang akan menjadi fokus dari tulisan ini, adalah bagian yang tidak kalah krusial dalam pewujudan PMD.

Letak Indonesia yang strategis menjadikan perairannya rentan terhadap berbagai jenis ancaman, termasuk ploriferasi ancaman keamanan non-tradisional. Ancaman keamanan non-tradisional sendiri dapat didefinisikan sebagai tantangan terhadap kelangsungan hidup yang berasal dari unsur-unsur non-militer yang meliputi, namun tidak terbatas pada terorisme, tindakan kriminal transnasional, dan kelangkaan sumber daya alam (Caballero-Anthony 2016). Pemerintah Indonesia telah mengidentifikasi sejumlah isu keamanan yang umumnya kerapkali muncul. Beberapa di antaranya seperti perompakan di laut, terorisme, illegal fishing, dan penyelundupan telah memiliki sejarah panjang di perairan Indonesia, khususnya di wilayah Laut Natuna, Laut Sulu-Sulawesi, dan Selat Malaka. Prevalensi ancaman keamanan nontradisional di wilayah-wilayah ini memiliki implikasi politik, ekonomi dan keamanan yang dapat menghambat pewujudan visi Indonesia untuk menjadi PMD (Kementrian Pertahanan Republik Indonesia 2015). Hal tersebut dikarenakan ancaman-ancaman yang telah disebutkan sebelumnya dapat mempengaruhi keamanan dan keselamatan pelayaran serta mengganggu proses distribusi sumber daya maritim Indonesia (Luhulima 2014). 
Salah satu strategi yang digunakan Indonesia dalam mengatasi berbagai ancaman yang ada di perairan Indonesia adalah melalui diplomasi pertahanan maritim. Secara tradisional, diplomasi pertahanan banyak dikaitkan sebagai instrumen realpolitik atau politik kekuatan/ kekuasaan. Seiring berjalannya waktu, diplomasi pertahanan pun mulai mengalami perluasan makna. Konsep ini tidak lagi hanya berfokus pada aspek yang umumnya didominasi oleh segelintir aktor internasional yang memiliki kapabilitas adidaya semata, namun mulai menginklusikan aspek yang berkaitan dengan stabilitas keamanan internasional secara keseluruhan. Dengan demikian, diskursus dalam diplomasi pertahanan pertahanan telah melampaui pembahasan mengenai unjuk kekuatanseperti gunboat diplomacy-dan mulai memperhatikan kooperasi dalam lingkup yang lebih luas, baik dari cakupan aktivitas, sektor, maupun aktor. Seperti upaya-upaya pertukaran informasi, latihan gabungan, hingga koordinasi keamanan. Tujuan dan sasarannya adalah merealisasikan kebijakan luar negeri sebuah negara yaitu keamanan nasional dan internasional yang lebih luas (Cottey 2004). Dengan semakin kompleksnya kontur keamanan internasional, kini sebagian besar negara di dunia telah melakukan diplomasi pertahanan, termasuk Indonesia. Tulisan ini akan menganalisis mengapa diplomasi pertahanan maritim menjadi pilihan yang diintensifkan oleh Indonesia dalam mengatasi ancaman keamanan non-tradisional di wilayah perairannya.

\section{Konsep Diplomasi Pertahanan Maritim}

Diplomasi merupakan tindakan yang dilakukan oleh aktor hubungan internasional demi mencapai kepentingannya secara damai tanpa menimbulkan kekacauan lebih lanjut. Diplomasi seringkali diasosiasikan dengan penggunaan kekuatan non-militer yang disebut dengan soft power dan menjauhi segala hal yang berhubungan dengan hard power atau militer. Negara merupakan salah satu aktor yang banyak menggunakan diplomasi dalam usaha mencapai kepentingan nasionalnya di dunia internasional. Salah satu jenis diplomasi yang digunakan adalah diplomasi pertahanan, yakni diplomasi yang umumnya dilakukan oleh institusi pemerintahan di bidang pertahanan demi mencapai kepentingan nasional, terutama dalam bidang pertahanan dan keamanan. Konsep ini juga dapat didefinisikan sebagai pengutilisasian senjata, peralatan, dan angkatan bersenjata sebagai instrumen pencapaian kepentingan negara dalam situasi damai. Dengan demikian, menggunakan aspek militer dalam proses diplomasi bukanlah hal yang selalu berhubungan dengan peperangan atau kekerasan. Diplomasi pertahanan umumnya dilakukan dengan setidaknya melalui 
tiga model berdasarkan intensinya: untuk mencapai 1) pembangunan kapasitas, 2) pembentukan kepercayaan, serta 3) pengembangan industri pertahanan (Mundayat et.al. 2018).

Sebagaimana yang telah dijelaskan, diplomasi pertahanan sepanjang perjalanannya telah mengalami perluasan yang signifikan, terlebih sejak tahun 1990-an. Hal ini menyebabkan adanya pergeseran paradigma dalam memaknai peranan dari elemen-elemen pertahanan, seperti pendayagunaan aparatur pertahanan-yang semula digunakan dalam konteks koersif-dalam agenda-agenda kooperatif di masa damai dengan negara atau pihak lainnya (Cottey 2004). Dalam tulisan ini, penulis mengonseptualisasikan diplomasi pertahanan di era kontemporer sebagai instrumen untuk mengurangi terjadinya konflik atau potensi kekacauan dan mendukung hubungan antar negara dalam mengembangkan kekuatannya untuk mempertahankan relevansi peranannya dalam menjaga stabilitas keamanan internasional. Intensi ini lantas menjadi pendorong pemerintahan Indonesia untuk mengintensifikasikan peranan dalam forum keamanan regional dan internasional. Menurut Cottey dan Foster (2004) diplomasi pertahanan dapat dilaksanakan dengan melakukan kegiatan-kegiatan berikut dengan negara mitra: 1) Pertemuan pejabat pertahanan militer dan sipil secara bilateral dan multilaterial; 2) Penugasan atase pertahanan; 3) Membuat perjanjian kerjasama pertahanan; 4) Melatih aparat pertahanan; 5) Pemberian rekomendasi terkait strategi pertahanan; 6) Pertemuan personil pertahanan militer dan sipil secara multilateral maupun bilateral; 7) Menerjunkan aparat pertahanan ke negara mitra; 8) Menugaskan kelompok pelatih ke negara mitra; 9) Menyediakan peralatan pertahanan bagi negara mitra; dan 10) Melaksanakan latihan gabungan.

Dalam memahami interaksi yang terjadi dibalik visi PMD, diplomasi pertahanan perlu dikontekstualisasikan dengan lebih rinci dalam kerangka kemaritiman, yakni melalui konsep diplomasi pertahanan maritim. Dengan demikian, diplomasi pertahanan maritim dapat diartikan sebagai bentuk politik internasional Indonesia yang dilakukan demi mencapai tujuan besar kemaritimannya. Dengan kata lain, diplomasi pertahanan maritim dapat dipahami sebagai kegiatan yang digencarkan untuk mencapai kepentingan keamanan maritim Indonesia: stabilitas maritim baik dalam keadaan damai maupun konflik. Konsep ini merupakan bentuk dari pemaksimalan kekuatan maritim yang dimiliki oleh Indonesia. Diplomasi tersebut dapat dilakukan dengan menggabungkan berbagai aspek, mulai dari hukum, instrumen diplomatik, hingga militer. Diplomasi maritim sendiri dapat diartikan pula sebagai turunan dari diplomasi pertahanan. Hal ini dapat dilakukan 
dengan dua cara yaitu memanfaatkan instrumen-instrumen maritim yang ada dan mengerahkan diplomat dalam menyelesaikan berbagai permasalahan dan ancaman kemaritiman Indonesia (CSIS 2018).

\section{Ancaman Keamanan Non-Tradisional di Perairan Indonesia}

Ancaman keamanan maritim non-tradisional di Indonesia memiliki beberapa bentuk dan berasal dari berbagai sumber. Beberapa di antaranya yang paling prominen adalah perompakan, terorisme, dan aktivitas kriminal transnasional. Menurut International Maritime Organization (IMO) perompakan di laut dapat didefinisikan sebagai tindakan menaiki kapal lain secara paksa dengan penggunaan atau ancaman penggunaan kekerasan yang bertujuan untuk merampas muatan kapal atau menahan awak dan penumpang kapal baik di laut internasional maupun di laut teritorial (IMO 2009). Dalam sebuah laporan yang diterbitkan International Chamber of Commerce (ICC) dan International Maritime Bureau (IMB) pada tahun 2020, perairan Indonesia merupakan lokasi dengan jumlah kasus perompakan terbanyak di Asia dan bahkan dunia selama beberapa tahun terakhir. Laporan tersebut menyebutkan bahwa perairan Indonesia yang berbatasan dengan wilayah negara lain yang rentan terhadap perompak adalah laut Sulu-Sulawesi. Adapun perairan internasional yang berbatasan dengan pesisir Indonesia yang rentan terhadap perompakan yaitu Selat Malaka.

Terorisme dapat didefinisikan sebagai tindakan-tindakan yang bertujuan untuk mencapai tujuan politik dengan cara menyebarkan rasa takut. Meskipun terorisme umumnya dilakukan di darat, terorisme di era kontemporer dapat berpotensi untuk dilakukan pula secara maritime, seperti melakukan pengeboman terhadap kapal laut atau penculikan awak dan penumpang kapal (Danish Institute of International Studies 2009). Bentuk terorisme maritim yang umum ditemukan di perairan Indonesia dan sekitar Indonesia adalah penculikan dan penyanderaan yang dilakukan oleh kelompok teroris. Berbeda dengan perompak, penculikan dan penyanderaan yang dilakukan teroris tidak hanya memiliki motif ekonomi namun juga mengandung motif politik. Salah satu kelompok teroris yang aktif beroperasi di perairan Indonesia dan sekitar Indonesia adalah Abu Sayyaf Group (ASG). Kelompok tersebut melakukan aktivitasnya di perairan Indonesia, Filipina, dan Malaysia serta di Selat Malaka dengan melakukan sejumlah penyanderaan terhadap nelayan dan awak kapal lainnya (Observer Research Foundation 2019). 
Selain terorisme dan perompakan, aktivitas kriminal transnasional turut menjadi salah satu ancaman keamanan yang kerapkali terjadi di perairan internasional. Bahkan, dampaknya dapat dirasakan di lebih dari satu negara sekaligus. Aktivitas kriminal transnasional dibedakan dari berbagai kejahatan laut lainnya karena sifatnya yang cenderung lintas-batas, permasalahannya yang unik, serta motifnya yang luas. Kendati demikian, secara umum pelaku dari tindak kejahatan ini dapat dikelompokkan menjadi dua berdasarkan modus operandinya yaitu kelompok kriminal yang memasok berbagai barang ilegal seperti narkoba, senjata, serta berbagai barang curian yang dikenal dengan istilah smuggling atau penyelundupan dan kelompok kriminal yang memperdagangkan jasa dan barang ilegal, seperti perdagangan manusia baik anak maupun dewasa yang dikenal sebagai trafficking. Dua jenis bisnis ini sering ditemukan di perairan Indonesia. Layaknya bisnis gelap pada umumnya, kejahatan transnasional memanfaatkan situasi tertentu demi mendapatkan keuntungan, dan negara-negara di Asia Tenggara-salah satunya Indonesia-dianggap memiliki kondisi yang menunjang agenda tersembunyi tersebut (United Nations Office on Drugs and Crime Research 2019). Terorisme dan perompakan memang merupakan masalah yang cukup akut di Indonesia, namun munculnya berbagai kejahatan transnasional yang kian terorganisir di wilayah ini juga tidak bisa dipandang sebelah mata.

Maraknya kejahatan transnasional-terlebih kejahatan berbasis maritimdi Indonesia dapat diatribusikan pada kondisi geografis Indonesia yang secara tidak langsung mendukung, sebagaimana negara ini merupakan negara ini merupakan salah satu titik transit penting dari perdagangan laut dunia. Sejalan dengan laporan United Nations Office on Drugs and Crime Research (UNODC) sebelumnya, berbagai penegak hukum di bidang maritim pun mengidentifikasikan bahwa ancaman utama yang ada di perairan Indonesia adalah perdagangan manusia serta penyelundupan benda terlarang seperti obat-obatan, senjata ilegal, dan berbagai komoditas lainnya (UNODC 2019). Mengingat sifat dari ancaman nontradisional ini yang cenderung terorganisir dan tersembunyi, penting untuk meningkatkan koordinasi pada semua tingkatan baik domestik maupun internasional. Kesinergisan ini merupakan langkah awal yang perlu dilakukan dalam menyusun keamanan maritim yang lebih ketat. Untuk mengakomodir kepentingan ini, pemerintahan pun meluncurkan dokumen Kebijakan Laut yang merupakan perluasan dari lima pilar utama PMD. Dokumen ini berisi tujuh prioritas utama dalam kebijakan maritim di masa pemerintahan Presiden Joko Widodo dan menetapkan sasaran dan prioritas dari keamanan maritim Indonesia (Moris dan Paoli 2018). 


\section{Upaya Diplomasi Pertahanan Maritim Indonesia dalam Menghadapi Ancaman Keamanan Maritim Non-Tradisional}

Indonesia melakukan berbagai upaya dalam menghadapi ancamanancaman keamanan non-tradisional yang telah disebutkan sebelumnya di wilayah perairannya. Salah satunya adalah melalui diplomasi pertahanan maritim. Hal tersebut dilakukan karena Indonesia memiliki kapabilitas yang terbatas dan kurang optimalnya alat utama sistem pertahanan (alutsista), baik dari segi kualitas maupun kuantitas, yang dimiliki oleh Indonesia (Febrica 2017). Diplomasi pertahanan yang dilakukan sendiri bersifat bilateral, multilateral, dan regional. Adapun kegiatan diplomasi pertahanan maritim yang dilakukan meliputi pelaksanaan latihan gabungan, operasi gabungan, pertukaran informasi, konsultasi, dan pertemuan pejabat senior maupun personil lainnya. Langkah-langkah ini umumnya dilaksanakan dengan beberapa negara yang berbatasan langsung perairan Indonesia. Negara-negara tersebut adalah Australia, Filipina, Malaysia, Thailand, Singapura, dan India. Tidak hanya itu, Indonesia juga melaksanakan diplomasi pertahanan dengan negara-negara lain yang menggunakan perairan Indonesia dan perairan Internasional yang berbatasan dengan pesisir Indonesia, seperti Korea Selatan, Jepang, dan Amerika Serikat.

\begin{tabular}{ccc} 
Negara Yang Terlibat & $\begin{array}{c}\text { Nama Kegiatan (Jenis } \\
\text { Kegiatan) }\end{array}$ & Institusi Terlibat \\
\hline & CORPAT (Patroli gabungan) & $\begin{array}{c}\text { TNI AL dan Royal } \\
\text { Australian Navy (RAN) }\end{array}$ \\
\cline { 2 - 3 } Indonesia dan Australia & $\begin{array}{c}\text { Exercise Cassowary } \\
\text { (Latihan gabungan) }\end{array}$ & TNI AL dan RAN \\
\cline { 2 - 3 } & $\begin{array}{c}\text { Exercise New Horizon } \\
\text { (Latihan gabungan) }\end{array}$ & TNI AL dan RAN \\
\cline { 2 - 3 } & $\begin{array}{c}\text { Koordinasi, pertukaran } \\
\text { informasi, latihan gabungan } \\
\text { secara insidentil }\end{array}$ & $\begin{array}{c}\text { Bakamla dan Australian } \\
\text { Border Force (ABF) }\end{array}$ \\
\hline Indonesia dan India & $\begin{array}{c}\text { INDINDO (Patroli gabungan } \\
\text { dan latihan gabungan) }\end{array}$ & TNI AL dan Indian Navy \\
\hline
\end{tabular}


Diplomasi Pertahanan Maritim Indonesia dalam Menghadapi Ancaman Keamanan Non-Tradisional: Upaya Mewujudkan Visi Poros Maritim Dunia

\begin{tabular}{|c|c|c|}
\hline \multirow{2}{*}{ Indonesia dan Malaysia } & $\begin{array}{l}\text { MALINDO JAYA (Latihan } \\
\text { gabungan) }\end{array}$ & $\begin{array}{l}\text { TNI AL dan Tentara Laut } \\
\text { Diraja Malaysia (TLDM) }\end{array}$ \\
\hline & $\begin{array}{l}\text { PATKOR MALINDO (Patroli } \\
\text { gabungan) }\end{array}$ & TNI AL dan TLDM \\
\hline \multirow[t]{2}{*}{ Indonesia dan Thailand } & $\begin{array}{l}\text { Sea Garuda (Latihan } \\
\text { gabungan) }\end{array}$ & $\begin{array}{l}\text { TNI AL dan Royal Thai } \\
\text { Navy }\end{array}$ \\
\hline & $\begin{array}{l}\text { PATKOR INDOTHAI } \\
\text { (Patroli gabungan) }\end{array}$ & $\begin{array}{c}\text { TNI AL dan Royal Thai } \\
\text { Navy }\end{array}$ \\
\hline \multirow{3}{*}{ Indonesia dan Filipina } & $\begin{array}{l}\text { PHILINDO EXERCISE } \\
\text { (Latihan gabungan) }\end{array}$ & TNI AL dan Philipine Navy \\
\hline & $\begin{array}{l}\text { PATKOR PHILINDO } \\
\text { (Patroli gabungan) }\end{array}$ & TNI AL dan Philipine Navy \\
\hline & $\begin{array}{c}\text { Konsultasi, pertukaran } \\
\text { informasi, latihan gabungan, } \\
\text { patroli gabungan }\end{array}$ & $\begin{array}{c}\text { Bakamla \& Philipine Coast } \\
\text { Guard }\end{array}$ \\
\hline \multirow[t]{2}{*}{ Indonesia dan Singapura } & Elang INDOPURA & $\begin{array}{l}\text { TNI AL dan Republic of } \\
\text { Singapore Navy (RSN) }\end{array}$ \\
\hline & $\begin{array}{c}\text { Pertukaran informasi dan } \\
\text { koordinasi }\end{array}$ & Bakamla dan RSN \\
\hline Indonesia dan Jepang & $\begin{array}{l}\text { Latihan gabungan dan } \\
\text { pertukaran informasi }\end{array}$ & $\begin{array}{c}\text { Bakamla dan Japanese } \\
\text { Coast Guard }\end{array}$ \\
\hline $\begin{array}{c}\text { Indonesia dan Korea } \\
\text { Selatan }\end{array}$ & $\begin{array}{l}\text { Pelatihan, Konsultasi, } \\
\text { pertukaran informasi }\end{array}$ & $\begin{array}{c}\text { Indonesia dan Korean Coast } \\
\text { Guard }\end{array}$ \\
\hline $\begin{array}{c}\text { Indonesia dan Amerika } \\
\text { Serikat }\end{array}$ & $\begin{array}{l}\text { Kesempatan pendidikan dan } \\
\text { konsultasi pejabat senior }\end{array}$ & $\begin{array}{c}\text { Bakamla dan United States } \\
\text { Coast Guard }\end{array}$ \\
\hline
\end{tabular}

\title{
Tabel 1.1 Diplomasi Pertahanan dan Maritim Bilateral Indonesia (Sumber: Diolah oleh Penulis)
}

\author{
Diplomasi Multilateral dan Regional Indonesia dalam \\ Menghadapi Ancaman Keamanan Maritim Non-Tradisional
}


Selain kerjasama bilateral, Indonesia juga melakukan berbagai kooperasi multilateral demi menghadapi berbagai ancaman maritim yang mungkin terjadi di perairannya. Sejalan dengan lingkaran konsentris dari kebijakan luar negeri Indonesia, prioritas kerjasama berfokus pada kawasan Asia terutama Asia Tenggara. Namun, hal tersebut bukan berarti Indonesia tidak menginisiasi kerjasama dalam lingkup yang lebih luas lagi. Beberapa kerjasama regional dan multilateral yang dilakukan Indonesia adalah seperti yang tertera pada tabel di bawah ini:

\begin{tabular}{|c|c|c|c|}
\hline Nama & Negara anggota & $\begin{array}{c}\text { Jenis } \\
\text { kerjasama }\end{array}$ & Topik kerjasama \\
\hline $\begin{array}{l}\text { Malacca Strait } \\
\text { Patrol }\end{array}$ & $\begin{array}{c}\text { Singapura, Indonesia, } \\
\text { Malaysia }\end{array}$ & trilateral & $\begin{array}{l}\text { Patroli terkoordinasi di } \\
\text { Selat Malaka }\end{array}$ \\
\hline Maphilindo & $\begin{array}{l}\text { Malaysia, Philipina, } \\
\text { Indonesia }\end{array}$ & trilateral & $\begin{array}{c}\text { Menangani } \\
\text { permasalahan } \\
\text { transnasional, patroli } \\
\text { laut, patroli udara di } \\
\text { Laut Sulu }\end{array}$ \\
\hline $\begin{array}{l}\text { ASEAN Maritime } \\
\text { Forum }\end{array}$ & ASEAN & multilateral & $\begin{array}{l}\text { memperkuat kerjasama } \\
\text { regional dan } \\
\text { internasional saja namun } \\
\text { minim dalam } \\
\text { penyelesaian konflik }\end{array}$ \\
\hline $\begin{array}{l}\text { ASEAN Outlook on } \\
\text { the Indo-Pacific }\end{array}$ & ASEAN & multilateral & $\begin{array}{c}\text { memandu berbagai } \\
\text { keterlibatan ASEAN di } \\
\text { wilayah tetangga yakni } \\
\text { Samudera Hindia serta } \\
\text { Asia-Pasifik }\end{array}$ \\
\hline $\begin{array}{l}\text { ASEAN Regional } \\
\text { Forum (ARF) Inter- } \\
\text { Sessional Meeting } \\
\text { on Counter- } \\
\text { Terrorism and } \\
\text { terrorism, } \\
\text { transnational } \\
\text { crimes }\end{array}$ & ASEAN & multilateral & $\begin{array}{c}\text { Menjaga keamanan } \\
\text { maritim dengan sharing } \\
\text { informasi, capacity } \\
\text { building, dan } \\
\text { mengembangkan } \\
\text { bantuan hukum timbal } \\
\text { balik }\end{array}$ \\
\hline
\end{tabular}




\begin{tabular}{|c|c|c|c|}
\hline $\begin{array}{l}\text { ASEAN Defence } \\
\text { Ministers' Meeting } \\
\text { (ADMM) }\end{array}$ & ASEAN & multilateral & $\begin{array}{c}\text { Dialog serta pengarahan } \\
\text { kebijakan pertahanan } \\
\text { dan keamanan }\end{array}$ \\
\hline $\begin{array}{c}\text { Southeast Asia } \\
\text { Cooperation and } \\
\text { Training (SEACAT) }\end{array}$ & $\begin{array}{l}22 \text { negara di dunia } \\
(2020)\end{array}$ & multilateral & Latihan bersama \\
\hline $\begin{array}{l}\text { Multilateral Naval } \\
\text { Exercise KOMODO } \\
\quad \text { (MNEK) }\end{array}$ & $\begin{array}{l}54 \text { negara di dunia } \\
(2020)\end{array}$ & multilateral & $\begin{array}{c}\text { Latihan bersama } \\
\text { berbagai angkatan laut, } \\
\text { melakukan kolaborasi } \\
\text { antara angkatan laut } \\
\text { seluruh dunia dalam } \\
\text { mencari solusi } \\
\text { permasalahan, serta } \\
\text { kesadaran akan } \\
\text { keamanan maritim. }\end{array}$ \\
\hline
\end{tabular}

\section{Tabel 1.2 Diplomasi Pertahanan Maritim Multilateral Indonesia}

(Sumber: Diolah oleh Penulis)

Kerjasama multilateral yang dilakukan Indonesia tidak hanya terbatas dari yang tertera pada tabel. Terdapat pula sejumlah inisiasi lain yang meliputi agenda-agenda seperti pertukaran informasi, latihan bersama, hingga penyelenggaraan dialog. Indonesia juga menjalin kooperasi dengan IMB, yang merupakan badan yang ada di bawah ICC dengan tugas mengumpulkan data aktual mengenai kejahatan di laut yang terjadi secara berkala (ICC-IMB 2020). Meskipun Indonesia masih dapat digolongkan sebagai negara dengan kasus kejahatan transnasional yang cukup tinggi, pada Januari 2020 lalu pemerintahan Indonesia setuju untuk tetap menjalankan kerjasama dengan IMB untuk mencegah adanya pembajakan dan perampokan lebih lanjut. Dengan demikian, hasil yang diharapkan dari adanya berbagai kerjasama multilateral ini dapat terselesaikannya dan tertanganinya masalah-masalah non-tradisional yang telah disebutkan secara damai (Asociation of Southeast Asian Nations 2019).

\section{Dampak Diplomasi Pertahanan Maritim bagi Keamanan Maritim Indonesia}

Sebagaimana yang disebutkan dalam laporan yang dikeluarkan oleh ICC-IMB pada tahun 2020, perairan Indonesia masih menjadi salah satu perairan paling rawan terhadap perompakan. Meskipun demikian, jumlah kasus perompakan di perairan Indonesia telah konsisten mengalami penurunan selama lima tahun terakhir (ICC-IMB 2020). 
Hal serupa turut dilaporkan oleh Regional Cooperation Agreement on Combating Piracy and Armed Robbery against Ships in Asia (ReCAAP) yang menyatakan bahwa selama lima tahun terakhir terjadi penurunan jumlah kasus perompakan di perairan Indonesia. Menurut laporan ReCAAP selama lima tahun terakhir, Indonesia dan negara-negara lainnya yang merupakan stakeholder di wilayah tersebut disarankan untuk tetap melaksanakan patroli baik secara unilateral, bilateral, maupun multilateral dan jika mampu meningkatkannya. Walaupun bukan faktor utama yang berkontribusi pada penurunan tren kejahatan transnasional maritim yang disebutkan, inisiasi-inisiasi patroli gabungan ini tidak dapat dipungkiri memiliki dampak tersendiri (ReCAAP 2015; 2016; 2017; 2018; 2019; 2020).

Namun, tren yang sama cenderung tidak terlihat dalam konteks penanggulangan terorisme maritime. Upaya dari negara-negara dengan perairan luas seperti Indonesia masih dianggap kurang mampu menanggulangi aktivitas-aktivitas teror di laut. Beberapa di antaranya yang prominen adalah jaringan ASG, kelompok teror yang beroperasi di Filipina namun turut menjalankan aksinya di sekitar perairan perbatasan Sulu-Sulawesi pada beberapa tahun terakhir. Tidak hanya Indonesia, beberapa negara lain yang berkepentingan di wilayah tersebut-Filipina dan Malaysia-juga belum dapat meminimalisir pergerakan dari ASG. Hal ini dapat diatribusikan pada belum teratasinya akar masalah dari dilakukannya aksi teror tersebut semula: masalah sosio-ekonomi. Karena itu, upaya penghentikan terorisme maritim di laut Sulu-Sulawesi membutuhkan lebih dari sekadar respon militeristik, namun juga konsolidasi dan akomodasi jangka panjang (IPAC 2019). Terlepas dari dampaknya yang kurang prevalen dalam konteks terorisme maritim, diplomasi pertahanan maritim lantas mampu membantu mengatalisasi proses ini. Pertukaran informasi dan penyamaan strategi akan mempermudah koordinasi antar pemerintah dan membantu menentukan langkah yang ideal untuk menghadapi ancaman tersebut (Storey 2016).

Langkah-langkah bilateral dan multilateral yang dilakukan Indonesia dalam konteks penanganan aktivitas kriminal transnasional memiliki implikasi yang lebih positif. Berdasarkan data yang dilaporkan IMB dan ReCAAP, aktivitas kriminal transnasional di Indonesia mengalami penurunan yang cukup signifikan. Terlebih yang termasuk dalam kategori smuggling dan trafficking. Capaian ini dapat diatribusikan pada adanya peningkatan kapabilitas dalam pendeteksian korban trafficking berkat semakin kuatnya kerjasama antar sesama negara Asia Tenggara (UNODC 2019). Hal ini pun turut terbantukan dengan adanya kerjasama trilateral antara Singapura, Malaysia, dan Indonesia 
dalam mengawasi area selat malaka yang notabenenya rawan terhadap penyelundupan. Sekali lagi, memang benar bahwa inisiasi-inisiasi ini merupakan satu dari sekian variabel yang berkontribusi pada stabilitas relatif yang telah dijelaskan. Namun, dampak dari upaya diplomasi pertahanan maritim yang telah Indonesia lakukan, terutama dalam kurun waktu lima tahun terakhir, tidak dapat ditafikan.

\section{Analisis Diplomasi Pertahanan Maritim Indonesia}

Intensifikasi upaya-upaya diplomasi pertahanan maritim yang diambil Indonesia dapat dikatakan sebagai manifestasi dan komitmen Indonesia terhadap visi PMD. Sebagaimana yang diutarakan oleh Kementerian Koordinator Bidang Kemaritiman dan Investasi (Kemenkomarves) Republik Indonesia, Visi PMD menjadi bagian dari preferensi kebijakan negara untuk membangkitkan kembali identitas 'negara maritim' Indonesia (Kemenkomarves 2017). Identifikasi diri ini berimplikasi pada sejumlah tindakan yang tercermin pada kebijakankebijakan yang digariskan dalam Buku Kebijakan Kelautan Indonesia. Buku tersebut mencantumkan 76 kebijakan utama Indonesia dalam mewujudkan visi PMD. Beberapa di antaranya adalah kebijakan yang diarahkan untuk meningkatkan keamanan maritim Indonesia baik melalui paradigma tradisional maupun non-tradisional (Kemenkomarves 2017). Dengan demikian, dapat diartikan bahwa peningkatan keamanan maritim merupakan salah satu bentuk refleksi identitas tersebut.

Selain itu, tindakan Indonesia untuk memprioritaskan upaya-upaya diplomasi pertahanan maritim juga dipengaruhi oleh status-quo dari kapabilitas pertahanannya. Masih minimnya kemampuan dari sistem dan institusi-institusi pertahanan dalam menjaga kedaulatan maritim, khususnya di perairan yang berbatasan dengan perairan negara lain atau perairan internasional, disadari oleh Indonesia. Kondisi ini ditegaskan oleh mantan Komandan Pangkalan Tentara Nasional Indonesia (TNI) Angkatan Laut (AL) I Belawan, Laksma Abdul Rosyid. Menurutnya, Indonesia memiliki keterbatasan alutsista dan personil dalam menjaga keamanan maritim. Oleh karena itu diplomasi pertahanan maritim menjadi bagian krusial yang dapat mengompensasi kekurangan ini dalam konteks menghadapi ancaman. Kurangnya alutsista dan personil yang dimiliki Indonesia dalam mengamankan perairannya dapat disubstitusikan dengan adanya bantuan militer dari negara lain untuk mengamankan perairan di sekitar Indonesia (Penerangan Pangkalan Angkatan Laut Indonesia I 2020).

Prioritas langkah pada diplomasi pertahanan maritim juga didasari oleh kesadaran dan pertimbangan Indonesia terhadap lingkungan sekitarnya. 
Dalam hal ini, Indonesia menyadari status-quo dari sistem internasional dan mempertimbangkan keberadaan maupun kapabilitas aktor-aktor lain. Terlebih aktor-aktor yang berpotensi memploriferasi ancaman keamanan, baik itu aktor negara maupun aktor non-negara seperti kelompok teroris, perompak, dan kriminal transnasional. Aktor-aktor non-negara dapat beroperasi secara transnasional sehingga upaya-upaya unilateral tidak cukup untuk mengatasi ancaman yang ditimbulkannya (Caballero-Anthony 2016) dan kenyataan ini pun diakui oleh Indonesia (Kementerian Luar Negeri Republik Indonesia 2019). Oleh karena itu diplomasi pertahanan menjadi pilihan yang rasional untuk menghadapi ancaman keamanan non-tradisional yang dimunculkan oleh aktor-aktor non-negara.

Pada akhirnya, upaya-upaya diplomasi pertahanan maritim yang dilakukan Indonesia-terlepas dari variasi intensitas implikasinyaberhasil meredam dan meminimalisir potensi bahaya di wilayah perairannya. Frekuensi diplomasi pertahanan maritim Indonesia berbanding terbalik dengan frekuensi kasus perompakan, terorisme, dan tindak kriminal transnasional di perairan Indonesia. Kapabilitas minim Indonesia dalam menjaga keamanan laut disuplementasi secara diplomatis, yang mana merupakan komponen penting dalam mewujudkan PMD. Memang diplomasi pertahanan maritim tidak dapat dengan serta-merta menghilangkan ancaman-ancaman ini dari perairan Indonesia, sebagaimana kompleksitas dari isu ini membutuhkan pendekatan yang lebih holistik. Namun, tidak dapat dinafikan bahwa pendekatan pertahanan dan keamanan yang telah diambil merupakan langkah terkalkulasi dan rasional, serta merupakan bagian penting dari rencana yang lebih luas dalam menghadapi ancaman keamanan non-tradisional di perairan Indonesia (IPAC 2020).

\section{Kesimpulan}

Sebagai negara maritim yang diapit oleh dua samudera dan dikelilingi oleh sejumlah jalur perdagangan laut tersibuk dunia, Indonesia memiliki potensi strategis yang cukup besar dalam aspek kemaritimannya. Besarnya peluang ini pun berbanding lurus dengan ancaman yang dihadirkan. Selaras dengan agenda PMD yang diinisiasi oleh Presiden Joko Widodo, lantas aspek pertahanan maritime menjadi salah satu prioritas yang turut diintensifkan. Langkah yang diambil oleh Indonesia dalam mempertahankan kedaulatan lautnya sebagian besar menggunakan diplomasi pertahanan maritimnya, seperti melalui mekanisme pembangunan kapabilitas dan pembentukan kepercayaan. Sejumlah kerjasama dan kolaborasi telah dicanangkan, baik dalam bentuk bilateral maupun multilateral. Hubungan yang terjalin termanifestasi dalam bentuk: mulai 
dari melakukan patroli laut bersama, latihan gabungan angkatan laut dengan berbagai negara, pertukaran informasi, hingga melakukan konsultasi dan dialog mengenai pertahanan dan keamanan. Sejalan dengan lingkaran konsentris kebijakan luar negerinya, Indonesia memfokuskan kerjasama pertahanan maritimnya dengan negara Asia Tenggara dan Pasifik. Meski demikian, kerjasama yang lebih luas juga diinisiasikan dengan sejumlah negara lain yang berkepentingan dan beroperasi di wilayah perairan Indonesia.

Upaya diplomasi pertahanan maritim Indonesia yang semakin gencar pada akhirnya berkontribusi pada meningkatnya kendali Indonesia atas lautnya. Hal tersebut tercermin pada menurunnya jumlah kasus perompakan, terorisme maritim, dan kriminal transnasional. Diplomasi pertahanan maritim menjadi bagian penting karena Indonesia memiliki kapabilitas terbatas dalam menghadapi berbagai ancaman keamanan di lautnya, terutama ancaman keamanan non-tradisional. Keterbatasan kapabilitas pengamanan laut menjadikan diplomasi pertahanan maritim sebagai suatu tindakan yang rasional untuk diambil bagi Indonesia. Walau terbukti telah memiliki sejumlah dampak yang cukup signifikan, diplomasi pertahanan maritim tidak bisa dijadikan satu-satunya upaya untuk memberantas isu keamanan dan pertahanan laut yang kompleks. Dalam jangka panjang, Indonesia masih perlu menyesuaikan postur pertahanan lautnya untuk menghadapi berbagai bentuk ancaman kontemporer, terlebih dalam kerangka mewujudkan visi PMD. Terkait dengan ini pula, pendekatan-pendekatan non-militer perlu untuk dipertimbangkan untuk mengatasi isu dengan lebih akomodatif dan preventif alih-alih mengandalkan cara-cara konfrontatif. 


\section{Daftar Pustaka}

\section{Buku dan Bagian dalam Buku}

Caballero-Anthony, M., 2016. "Understanding Non-Traditional Security”, dalam Caballero-Anthony, M. (ed.) An Introduction to NonTraditional Security. London: SAGE Publishing.

Cottey, Andrew \& Anthony Foster, 2004. Reshaping Defence Diplomacy: New Roles for Military Cooperation and Assistance. London: Routledge.

Luhulima, C. P. F., 2014. "Keamanan Maritim dalam Bingkai Poros Maritim Dunia", dalam Khanisa \& Farhana, F. (ed.) Keamanan Maritim ASEAN dalam Perspektif Ekonomi Politik Indonesia. Jakarta: LIPI Press.

Morris, Lyle J \& Giacomo Persi Paoli, 2018. A Preliminary Assessment of Indonesia's Maritime Security Threats and Capabilities. Cambridge: RAND Corporation.

\section{Artikel Jurnal}

Apriyana, Mochammad Andrey, 2019. "Kerjasama Trilateral dalam Menangani Ancaman Maritim di Perairan Sulu", Journal Ilmu Hubungan Internasional, 7(3): 1405 - 1416.

Keliat, Makmur, 2009. "Keamanan Maritim dan Implikasi Kebijakannya Bagi Indonesia”, Jurnal Ilmu Sosial dan Ilmu Politik, 13(1): 111 - 129.

Mudayat, Aris Arif et. al., 2018. "Diplomasi Pertahanan Indonesia Dalam Mewujudkan Poros Maritim Dunia”, Jurnal Prodi Diplomasi Pertahanan, 4(2): 21 - 39.

Storey, I., 2016. "Addressing the Persistent Problem of Piracy and Sea Robbery in South East Asia”, Perspective, 30: 1-11.

Suproboningrum, Lintang, 2018. "Peran Diplomasi Maritim dalam Keberhasilan Patroli Terkoordinasi Indonesia-MalaysiaSingapura untuk Menekan Angka Pembajakan dan Perompakan Laut di Selat Malaka”, Jurnal Hubungan Internasional, 11(1): 19-38.

\section{Working Paper}

Center for Strategic and International Studies, 2018. "Menerjemahkan Visi Poros Maritim Global ke dalam Kerangka Diplomasi Pertahanan 
Maritim dalam Kebijakan Luar Negeri Indonesia di Era Jokowi”, CSIS Working Paper Series, Januari.

Danish Institute for International Studies., 2009. "Piracy, Maritime Terrorism, and Naval Strategy", DIIS Report, No. 2.

Institute for Policy Analysis of Conflict, 2019. "Protecting the SuluSulawesi Seas From Abu Sayyaf Attacks", IPAC Report, No. 53, Januari.

, 2020. "Stopping Abu Sayyaf

Kidnappings: An Indonesian-Malaysian Case Study", IPAC Report, No. 53, Maret.

Observer Research Foundation, 2019. "Maritime Terrorism in Asia: An Assessment”, ORF Ocassional Paper, No. 215, Okctober.

\section{Publikasi Resmi}

Annual Report 2015: Piracy and Armed Robbery Against Ships in Asia, 2016. Singapore: ReCAAP.

Annual Report 2016: Piracy and Armed Robbery Against Ships in Asia, 2017. Singapore: ReCAAP.

Annual Report 2017: Piracy and Armed Robbery Against Ships in Asia, 2018. Singapore: ReCAAP.

Annual Report 2018: Piracy and Armed Robbery Against Ships in Asia, 2019. Singapore: ReCAAP.

Annual Report 2019: Piracy and Armed Robbery Against Ships in Asia, 2020. Singapore: ReCAAP.

Annual Report 2020: Piracy and Armed Robbery Against Ships in Asia, 2021. Singapore: ReCAAP.

ASEAN Outlook on the Indo-Pacific: Final, 2019. Jakarta: Association of Southeast Asian Nations.

Buku Putih Pertahanan Indonesia, 2015. Jakarta: Kementerian Pertahanan Republik Indonesia.

Declaration of the Seventh Ministerial Conference of the Bali Process on People Smuggling, Trafficking in Persons and Related Transnational Crime (Bali Process), 2018. Bali: Bali Process. 
Kebijakan Kelautan Indonesia, 2017b. Jakarta: Kementerian Koordinator Bidang Kemaritiman Republik Indonesia.

Memorandum Kerja Sama Antara Badan Keamanan Laut Republik Indonesia dengan Japan Coast Guard di Bidang Keamanan dan Keselamatan Maritim, 2019. Jakarta: Kementerian Luar Negeri Republik Indonesia.

Memorandum Saling Pengertian Antara Badan Keamanan Laut Republik Indonesia (Bakamla) dan Penjaga Pantai Filipina (PCG) Tentang Kerja Sama Keamanan Maritim. Kementerian Luar Negeri Republik Indonesia.

Memorandum Saling Pengertian Antara Badan Keamanan Laut Republik Indonesia dan Penjaga Pantai Korea Tentang Kerjasama Keamanan Maritim. Kementerian Luar Negeri Republik Indonesia.

Piracy and Armed Robbery Report for the Period 1 January-31 December 2020, 2021. London: International Chamber of CommerceInternational Maritime Bureau.

Plan of Action for the Implementation of the Joint Declaration on Maritime Cooperation Between the Government of the Republic of Indonesia and the Government of Australia. Kementerian Luar Negeri Republik Indonesia.

Rencana Kerja Antara Badan Keamanan Laut Republik Indonesia dan Penjaga Pantai Amerika Serikat Dalam Rangka Pelaksanaan Memorandum Saling Pengertian Tentang Kerja Sama Maritim Antara Republik Indonesia dan Amerika Serikat, 2017. Jakarta: Kementerian Luar Negeri Republik Indonesia.

Resolution A. 1025 (26) "Code of Practice for the Investigation of Crimes of Piracy and Armed Robbery against Ships", 2009. London: International Maritime Organization.

Surat Pernyataan Kehendak Antara Badan Keamanan Laut Republik Indonesia dan Angkatan Laut Republik Singapura Tentang Pertukaran Informasi di Bidang Keamanan dan Keselamatan Laut, 2019. Jakarta: Kementerian Luar Negeri Republik Indonesia.

United Nations Office on Drugs and Crime Research, 2019. "Transnational Organized Crime in Southeast Asia: Evolution, Growth and Impact”. Vienna: United Nations Office on Drugs and Crime. 


\section{Artikel Daring}

Kementerian Luar Negeri Republik Indonesia, 2019. "Kejahatan Lintas Negara" [Daring]. Tersedia dalam [https://kemlu.go.id/portal/id/ $\mathrm{read} / 89 /$ halaman list_lainnya/kejahatan-lintas-negara] (Diakses [16 Februari 2021]).

Ministry of Defense Singapore, 2019. "Singapore and Indonesia Navies Celebrate 25th Edition of Exercise Eagle Indopura" [Daring]. Tersedia dalam [https://www.mindef.gov.sg/web/portal/mindef/news-andevents/latest-releases/article-detail/2019/july/24jul19_nr] (Diakses [6 Februari 2021]).

Penerangan Pangkalan Angkatan Laut Indonesia I, 2020. "Danlantamal I: Lantamal I Siap Amankan Selat Malaka” [Daring]. Tersedia dalam [https://lantamal1-koarmada1.tnial.mil.id/NEWS/tabid/62/articleType/ArticleView/articleId/1825/Default.aspx] (Diakses [10 Februari 2021]).

Puspen TNI, 2019. "Latihan Bersama Sea Garuda 2019 Resmi Dibuka” [Daring]. Tersedia dalam [https://tni.mil.id/view-157468-latihan-bersama-sea-garuda-2019-resmi-dibuka.html] (Diakses [6 Februari 2021]). , 2020. "TNI AL Gelar Patroli Terkoordinasi Dengan AL India" [Daring]. Tersedia dalam [https://www.tnial.mil.id/berita/17041/ TNI-AL-GELAR-PATROLI-TERKOORDINASI-DENGAN-AL-INDIA/] (Diakses [6 Februari 2021]). 